\title{
A propósito de la jurema. Reflexiones sobre el campo religioso brasileño ${ }^{1}$
}

\author{
Fernando Giobelina Brumana \\ Universidad de Cádiz
}

\begin{abstract}
RESUMEN: A partir de la presentación de un par de ceremonias del culto de jurema, este trabajo se vuelca en el análisis de ciertas cuestiones del campo religioso brasileño. Los aspectos destacados son, fundamentalmente, la dinámica entre agencias religiosas y los sectores eruditos que se interesan en el estudio de las religiones subalternas, las redes de agencias - su densidad, los diversos trayectos que permiten los vínculos entre agentes de diversa legitimidad etc. -, la búsqueda de un valor operacional para "sincretismo", la homogeneización del campo, es decir, la absorsión de cultos de lógicas débiles por otros de lógicas fuertes.
\end{abstract}

PALABRAS-CLAVE: religiosidad popular, catimbó, jurema, umbanda, estudios religiosos.

A mediados de 2001 comencé una investigación sobre el culto de la jurema, como continuación de mis trabajos sobre la umbanda y el candomblé. El trabajo de campo, como en los casos anteriores, lo llevaba a cabo en São Paulo, en casa de un pernambucano migrado hacía décadas. Este hombre había sido "hecho" en el candomblé dentro de la línea del Pai Adão, en Recife, donde, al mismo tiempo, fue iniciado por un catimbozeiro muy reconocido. $\mathrm{Al}$ año siguiente del comienzo de este estudio, hice una estancia en la Universidade Federal de Pernambuco dentro del Programa de Cooperación Interuniversitaria del Gobierno Español. 
Fue en esta circunstancia que se produjo la primera incursión con la que se inicia este texto, que para mí tenía el paradójico encanto de, por una vez, ser llevado a campo, y serlo de una manera casi turística que me permitía ser testigo de una manera no comprometida y puntual de lo que en mi propia labor etnográfica siempre tiene la carga y la densidad del contacto prolongado e intenso.

Las descripciones que siguen, si es necesaria la aclaración, no pretenden de manera alguna ser una etnografía de las casas visitadas; respecto a ellas son más bien una aproximación casi periodística, similar, por otro lado, a la que antecesores como Bastide o Mario de Andrade habían tenido en los años 30 y 40 con el catimbó. De todas maneras, lo presenciado en las ceremonias descritas me permite abrir la reflexión al campo religioso, a sus articulaciones y dinámica. Pero en buena medida, el objeto de este texto es más bien la propia incursión, sus circunstancias, las relaciones implicadas, etc.; es decir, las condiciones de los estudios de la religiosidad subalterna brasileña, la relación entre mundo académico y mundo religioso.

Es en este punto, el de la visita grupal guiada, donde la acción comienza; acción que me parecía reproducir otras ocurridas muchas y muchas veces. Salvas sean las distancias con nuestro equipamiento tecnológico - coches, móviles, grabadoras, equipos fotográficos -, ¿̨no serían muy parecidas las incursiones en estos mismos barrios de investigadores de medio siglo antes o aún más? Al menos la misma fascinación por ese margen urbano, social, religioso. Al menos ese sentimiento de orgullosa propiedad que mal disimulan los investigadores "nativos", propiedad hecha de conocimiento antiguo, de mucho trato, de más de una aventura en común. 


\section{Noches en la periferia de Recife}

Noche en la periferia de Recife; cuatro coches venidos cada uno de un rincón diferente de la ciudad. El Sítio del Pai Adão nos servía de punto de reunión ya que nadie sabía cómo llegar a nuestro destino, el terreiro de Dona Maria, a pesar de las detalladas explicaciones que ésta había dado cuando pasó por el Departamento de Antropología de la Universidad para confirmar la invitación a la mesa de jurema. Todo había comenzado unos días antes, con mi llegada a la ciudad y mi pedido de contacto con este mundo al que me había asomado en otras estancias anteriores y que ahora pretendía explorar de manera más sistemática. El teléfono había funcionado en manos de la gente del departamento hasta que, entre varias posibilidades, se optó por ésta a la que ahora estábamos acudiendo. Como Dona Maria - y el espíritu que en algún momento la poseería - no se cansarían de decir, era una ceremonia hecha para nosotros. Nosotros: la plana mayor de los estudios religiosos en Pernambuco, varios alumnos suyos de doctorado y yo, el invitado "gringo".

Pero aún no habíamos llegado y nadie sabía cómo hacerlo. En el Sítio nos apelotonamos frente a la puerta de la casa de Mãe Mãezinha - por otro lado, la mãe-de-santo de Pedro, el juremeiro con quien había comenzado yo a trabajar en São Paulo unas semanas antes -, que nada sabía de Dona Maria ni de su terreiro. El tiempo pasaba y nadie atinaba a dar una solución, hasta que por fin aparecieron dos muchachas que dijeron que ellas sí sabían, se montaron en nuestro coche y nos guiaron por calles oscuras, atravesando puentes de arroyos, girando en casi todas las esquinas. Tras un cuarto de hora llegamos a un terreiro, pero, jay!, no era el que buscábamos. De todas maneras, allí nos pudieron dar con precisión las coordenadas de nuestro objetivo y, tras otro cuarto de hora en que varias veces nos llamamos de coche a coche por teléfono móvil para orientarnos, llegamos. 
Un edificio de construcción reciente, separado de la calle por un muro y un pequeño patio embaldosado, con la vivienda en los altos y la planta baja dedicada al templo, en el que nos estaban esperando hacía tiempo. Dona Maria, una morena corpulenta de edad mediana y potente voz, llegó a la puerta y nos hizo entrar al templo, una amplia sala alicatada hasta el techo, con luces fluorescentes, con un ventilador de techo que, pleno invierno, no estaba funcionando, con tres líneas de sillas de madera y otras dos contra las paredes laterales. En las paredes, algunos dibujos, fotografías y poemas en cartulinas coloridas que recuerdan que el local de día funciona como guardería infantil ("Que bom matar aulas!"; "Música. Casa torta: quem mora na casa torta/ sem janela e sem porta?/ Um gato que usa sapato/ e tem seu retrato no quarto/ uma florzinha pequeneninha/ de bainha curtinha/ um elefante/ com rabinho de brabante/ um papel de óculos e chapéu/ um botão que toca o violão essa não/ um pente com dor de dente/ ai meu dente!"). Apoyados provisoriamente en los vanos de dos puerta, un par de estandartes de maracatu ("Maracatu Nação Encanto de Alegria") que la dueña de casa nos muestra y comenta con orgullo.

Al frente, y con media docena de sillas rodeándola, la mesa - la mesa de jurema que en sentido estricto no se iría a abrir esta noche - cubierta por un mantel blanco sobre el que ya se habían dispuesto unos jarrones con flores - uno blanco en el centro, rodeado de un gran collar de conchillas; a los costados dos más pequeños de cristal, dentro de sendos recipientes también de cristal. Detrás de la mesa se abría un pequeño recinto con dos estanterías cubiertas de paños blancos apoyadas en sus paredes; en ellas se amontonaban plantas, flores bastante marchitas - las que no eran de plástico - maracas, collares rituales, sombreros de los mestres, arcos y flechas de los caboclos, montones de botellas de bebi- 
das alcohólicas (sidra artificial, cerveza, vino dulce, cachaça, whisky), estatuillas de pomba gira y de mestres, copas y vasos llenos de agua (las princesas de jurema, supongo). En lugar destacado, y sobre una base que lo elevaba medio metro del resto de los objetos, un recipiente de madera con un par de cabezas descarnadas de cabras, un gran vaso de agua y otros objetos indiscernibles. En una pequeña mesa apartada, dos estatuillas de pretos velhos - hombre y mujer; apoyadas en ellas las únicas pipas de anjico que aquí vi, las típicas pipas utilizadas en las mesas de jurema a diversos efectos y que se emplean al revés (se sopla en la cazoleta para que el humo salga por la boquilla). Pegada a una de las paredes, una tela con una representación demoníaca, una figura entre vegetal y esquelética que enarbolaba un tridente y tenía a sus espaldas una botella de aguardiente. Firma indescifrable y un 84 que imagino sería el año de su realización.

Los visitantes, una decena aproximadamente, no seríamos los únicos en asistir a la ceremonia; alguna gente del barrio que nos igualaba en número empezó a entrar y a ocupar las sillas. Un par de mujeres lo hizo a la mesa, a invitación de Dona Maria. Frente a ambos contingentes, uno mucho menor, el de los oficiantes y sus auxiliares, cinco en total, identificables por sus ropas blancas a las que, en el caso de la dueña de casa, se agregaba un turbante.

Lo ocurrido en las casi dos horas que estuvimos aquí lo reconstruyo ahora (febrero 2002) con mi siempre poco confiable memoria, el par de cassettes que gravé, las veinte fotografías que hice, las pocas anotaciones de mi cuaderno que empiezan casi cuando "los trabajos" iban a dar comienzo: "Dona Maria nos pone colonia en las manos a cada uno de nosotros. Dice que "água de colônia espírita" siempre es fuerte, pero que ella la prefiere más suave. Muestra un garrafón de cristal tallado lleno de jurema. Todos nosotros hacemos sonidos y gestos admirativos del supuesto objeto artístico - y de su embriagador contenido, quizás tam- 
bién. Aparece una muchacha con un niño (¿nieto de I.?) al que hace que nos muestre cómo se toca en el maracatu, como hace Xangô en tierra, como se 'bate cabeça', etc.".

Comienzo de la ceremonia. Dona Maria y un hombre delgado de bigotes, Betinho, se colocaron detrás de la mesa. Poco a poco nos quedamos en silencio y entonces Dona Maria, con voz monocorde pero segura, hizo una invocación que me sonó a oración espírita y de la que registro las palabras finales: "A Santíssima Trindade, nossos anjos da guarda, nossos guias guardiães, Deus poderoso. Que os bons espíritos que fiquem entre nós. Louvado seja nosso Jesus Cristo". Inmediatamente desgranó un Padre Nuestro, coreado por la asistencia en pleno, que, dijo al finalizarlo, "se dedica aos espíritos de boa vontade. Que nos tragam a paz, nos tragam muito axé". Y sin más dilación: "Barabaô Exu. Vamos salvar Exu". Entonó entonces las estrofas de un primer ponto: "Aiê, aiê baba/ eu vou abrir meu caipô/ Lá no caminho, eu deixei meu sentinela/ deixei barabaô tomando conta da cancela/ deixei seu Malunguinho tomando conta da cancela,/ deixei Exu Veludo tomando conta da cancela. Barabaô Exu".

Los asistentes habituales, que habían acompañado el ponto con golpes de palmas y, más tímidamente, con sus voces, respondieron "Barabaô". Dona Maria emprendió entonces otro ponto: "De quem é aquela casa/ com porta e sem janela?/ É a casa de Exu/ Bombonjira mora nela”. El público entró en la segunda estrofa y repitió la cantiga varias veces, hasta que la propia Dona Maria la cortó para exclamar "Barabaô Exu". Su compañero tomó el relevo: "Salve Exu, salve". Marcando el ritmo con las palmas, acompañado por la asistencia, comenzó una serie de pontos de Exu; unas veces sería él quien los iniciase, otras Dona Maria: "Exu que tem duas cabeças/ ele vai na gira com fé,/ uma é de Satanás, eu não quero,/ a outra é de Jesus Nazaré”. A partir de este momento, una maraca se incorporaba a la celebración; las palabras registra- 
Revista de Antropologia, São Paulo, USP, 2005, v. 48 No 2.

das por mi grabador se hacen más inextricables y bastantes fragmentos se me escapan: "A Exu, ele pisa num toco de um galho só,/ ele pisa no toco,/ pisa no galho,/ pisa no toco de um galho só [...]”. "Meu chapeuzinho tá peqenininho,/ salve a coroa do rei Malunguinho." "Malunguinho na mata é rei." "Ele é preto, ele é pretinho, salve a coroa do rei Malunguinho."

No había pasado mucho tiempo, unos cinco minutos si tanto, e Dona Maria daba esa etapa ceremonial por superada: "Exu já bebeu, Exu comeu/ Exu vai embora/ que Deus lhe mandou/ o galo cantou". La gente cantaba, batía palmas, alguien seguía con la maraca hasta que Dona Maria cortó y dijo: "Que Exu leve tudo de ruim. Não estamos para fazer o mal mas para fazer o bem. As coisas ruins que Exu leve e traga as boas".

Tras este "despacho" de Exu se pasó a una nueva fase de la ceremonia, la defumação. Una asistenta trajo un recipiente de cerámica en el que había carbón ya encendido sobre el que Dona Maria colocó algunas hierbas que pronto largaron humo con un olor tan característico. Nuevo ponto: "Defuma com as ervas da jurema/ defuma com arruda e guinél alecrim, benjuim e alfazema/ vamos defumar filhos de fé”. Durante varios minutos, uno por uno nos acercamos a la pequeña humareda y con las manos hicimos como que cogíamos el humo y nos los pasásemos por el cuerpo, la cabeza, la extremidades. Cuando terminamos, mientras el incensario era retirado, nuevos pontos, siempre entonado por Dona Maria, de los que sólo rescato un par: "Esta casa já foi defumada/ foi São Miguel que a defumou/ as mazelas que nela tiver/ senhor São Miguel com a espada levou. Esta casa é de Deus/Inimigo não entra/ se estiver na porta de fora”.

Un pequeño descanso en el que Dona Maria volvió a empuñar su frasco de colonia y a ofrecerlo al público: "Quem não recebeu perfume"? Pocos minutos y se reanudaba la ceremonia. Era hora de cantar para los caboclos. Dona Maria inició el ponto: "Êee, Caboclo Sete 
Flechas no congá/ saravá seu Sete Flechas/ ele é o rei da mata/ quando toca aqui na gira / saravá, sua Flecha Mata". Otro ponto: "Quando os caboclos desceram lá do alto da serra/ trazia no peito uma cobra coral/ vamos saravar, meu pai, seu Sete Flechas". Y otro más: "Caboclo não tem caminho para caminar/ ele caminha por cima das folhas/ por baixo das folhas/ em qualquer lugar,/ o que caboclo".

Betinho inició otras cantigas: "Caboclo Maia, Caboclo Maia/ Caboclo Maia é rei/ Caboclo Maia eu quero ver. A mata é do caboclo Maia/ eu estava na mata de caboclo Maia”. Varias más que no logro ahora descifrar. El tiempo dedicado a este espíritu no había sido mucho y ni siquiera se lo hizo bajar a tierra; ya se había advertido en un comienzo que esta sesión dedicada a los profesores iba a ser corta, porque, suponía Dona Maria, mañana tenían que madrugar para dar clase - aunque, de hecho, la Universidad estaba en huelga desde hacía más de un mes. Varios intentos de Betinho para prolongar las cantigas fueron inmediatamente cortadas por la jefa de la casa. Tiempo, pues, para despedir a los caboclos: "Caboclo vai embora/ pra cidade da jurema,/ Deus lhe está chamando,/ ele vai ser coroado/ na cidade da jurema/ com uma coroa de pena”.

Dona Maria insitió entonces con la preocupación por el tiempo: "Algunos van a viajar mañana, otros van a dar clase. Estamos corriendo; no podemos terminar muy tarde. Vamos a cantar para Jurema ahora... vosotros querías ver Jurema...". Betinho invocó la Jurema: "Louvado seja o Senhor Jesus Cristo. Quem pode mais que Deus?". Respuesta de todos: "Ninguém" - repetido tres veces. "Viva Deus! Salve a força e poder! Salve a essência divina! Salve a Jurema sagrada!". Entonó en seguida una cantiga, repetida muchas veces entre palmas y golpes de maraca: "Vou salvar minha Jurema/ para ela me ajudar/ ela me deu toda a ciência/ para eu poder trabalhar/ para o mestre trabalhar". Dona Maria: "Jurema/ é um povo encantado/ é um pau de ciência/ que todos querem saber". 
Revista de Antropologia, São Paulo, USP, 2005, v. 48 no 2.

"Eu dou ciência a você/ mas se queres ciência/ eu dou jurema a você." De nuevo, Betinho: "A jurema é minha madrinha/ Jesus é meu protetor [...]". En medio de los cánticos y de las palmas, Dona Maria había recibido su mestre, Zé Ferreira, que, apenas, se ha apoderado del cuerpo de su caballo quiere comunicarse con la gente que lo esperaba:

"Louvadas sejam as tres pessoas da santíssima trindade, louvada seja a minha jurema sagrada, louvado seja todo esse povo que está aquí. Louvado seja nosso Senhor Jesus Cristo. Como vão todos vocês que estão por aqui? [Murmullos de bien, muy bien.] Essa recepção de agosto... Eu gosto de uma coisa grande, que todo mundo deve estar comendo e bebendo. Graças a Deus, eu não sou espírito pobre [Risas suyas y del público.]"

Empieza a saludarnos a uno por uno: "Como vai vosmecê? Como é que vai minha senhora?". Respuestas de rigor que permiten continuar rápidamente la ronda de saludos. "Bem, graças a Deus." En mi caso: "Quando vosmecê voltar aqui outra vez, vosmecê vai voltar muito melhor, não é não?". Zé Ferreira inicia una cantiga: "Eu entrei dentro da mata/ eu fui visitar um dendezeiro/ a mata é do Zé Ferreira [...]/ ô jurema". Otra: "Eu estava na beira da praia/ tocando no meu violão/ veio uma morena bonita/me deu um abraço/ e apertou a minha mão/ aaa, me cave um buraco/ me bote no chão/ para ver se o marreco fica direito/ mas eu sou marreco mas tenho dinheiro/ a falta de moça eu vou resolver/ por falta de moça/ não fico solteiro".

Zé Ferreira termina la cantiga con una carcajada: "Vocês desculpem, mas eu sou assim mesmo. Para quem não me conhece, meu nome é Zé Ferreira... Eu quero meu chapéu...”. Insiste hasta que le traen un viejo sombrero, en muy mal estado, que se coloca en la cabeza. "Eu gosto deste chapéu. Todos aqui escondem, brincam, mas eu gosto dele, né? É como você gostar de uma mulher; ela pode ser velha, troncha, aleijada, 
mas é sua mulher, não é não? De mais ninguém.” Inicia otra cantiga: "Meu cachimbo está no toco e já mandei você tirar/ fuma cachimbo e não sabe fumar, só manda fumaça quem sabe mandar" (mandar fumaça: acción de hechicería hecha con tabaco muzclado con diversas hierbas).

Encara a una de mis compañeras que ha permanecido sentada todo el tiempo y le pregunta por qué no se pone de pie como todo el mundo. La mujer: "Eu pensei que era para dançar...". "Não" - exclama el espíritu - "Aqui ninguém dança; ninguém é obrigado." Da una carcajada, que quizás indique que sí, qué este es un lugar donde se tiene poder para obligar, y que "dançar" (una de cuyas acepciones es "hundirse"), ellos - el espíriu y su "caballo"- ya han hecho danzar a más de uno. "Foi só por isso?" - pregunta el mestre. "Só. Eu gosto muito do senhor". "Graças a Deus", concluye el espíritu. Se acerca en seguida a una de las mujeres que su caballo había hecho sentar junto a la mesa, una cuarentona blanca de cabello castaño y gafas, con aspecto de clase media baja y un aire triste y enfermizo: "Tá melhor, não, dona?" Una respuesta que no escucho. "Tá não." Comienza una breve entrevista de la que sólo me llega el final en boca de Zé Ferreira: "Então vou passar e vou sair [...], já é o remédio certo", contestada por carcajadas de los testigos. Por lo que parece, la mujer es víctima de acciones de hechicería provocadas por un catimbozeiro. "O catimbó é isso que você se impressiona. Se você mora junto à casa de um catimbozeiro, o catimbó é o que você se impresiona, você enlouquece e o catimbozeiro fica. Você tem que topar com ele, olho no olho, dente no dente, espada na espada. Aí ele cai fora, o inimigo". Un fuerte carraspeo, unas palabras que se me ocultan - sólo escucho una bendición: "Deus te abençoe" - y una nueva cantiga: "Distampei a minha panela para salvar meu maracál vou tampar [...]. Tu tava na rua do jeito que eu quero". Y otra más: "Oi pisa no massapê e escorrega/ quem não sabe andar escorrega”. 
Revista de Antropologia, São Paulo, USP, 2005, v. 48 no 2.

Habla Zé Ferreira: "Eu queria muito, eu gostaria muito, que na minha festa estivesse todo esse povo (por nosotros) que eu não tinha visto nunca. Vai ter festa o dia todinho. Começa que hora?” Alguien responde: "Desde meio dia" “¿Y hasta que hora?", pregunta Zé. "Até dez da noite”, dice la misma voz. Zé se dirige al público para hablar de su fiesta:

"Enquanto tiver cachaça, enquanto tiver mulher, enquanto tiver bebida, enquanto tiver sorvete, todo mundo vai, todo mundo fica. Eu faço a minha festa, porque meu povo me dá tudo, meu povo dá conta. Espírito trabalhador, espírito ganha. Agora espírito preguiçoso pega um canto da parede e só vai ter cusparada, não é não, minha filha? Agora espírito que trabalha faz. Todo ano tenho minha festa, por que não vai ter esse ano? Eu não gosto disso. Ela [Dona Maria, su caballo, es de suponer] está muito preocupada com isso e comigo está esquecendo. Quero minha festa e, se não fizer, eu faço. Agora, faço de meu modo e vai ser pior. Eu encho a casa de ladrão, de rapariga, de maconheiro e vai ter uma festa. Eu falo e eu faço. Eu faço ou não faço? [Murmullos risueños: faz, faz.] Eu faço minha festa sozinho. Agora, se ela combinar comigo de fazer a minha festa, aí eu faço. Eu não sou espírito preguiçoso, eu trabalho, não é Dona Goreti, dona mulher? Agora espírito que trabalha não leva cusparada na cara, é ou não é?"

Satisfecho con la reacción de "su pueblo" y de nosotros, los visitantes ricos, el espíritu comienza a encararnos uno a uno: "Tu vai me dar o que para minha festa?", pregunta a una mujer. "O que você quiser", le responde ésta, pero el espíritu busca una respuesta menos diplomática y más comprometida, para lo que usa un equívoco sexual, que provoca las risas de todos: "Não, 'o que você quiser' você sabe o que é, e você não vai me dar. Eu tomo cachaça, tomo vinho e tomo jurema de vez em quando para descongestionar". Más risas, el estereotipo de los mestres no hace pensar precisamente en la abstinencia. Comienza a hacer pedi- 
dos específicos: "Você vai me dar dois engradados de cerveja. Que é pro povo beber, você está imaginando o quê?". De nuevo risas. Inicia la misma operación con una de las alumnas que venía con nosotros, una gaúcha: "Você mora aqui, não mora?" "Por enquanto, moro." "Mas você não é daqui?" "Não". Pero el espíritu no quiere más detalles: "Então o que você vai me dar?” La respuesta no se escucha, pero debe ser positiva, porque Zé dice:

"Todo mundo vai me dar, por que que não vou fazer minha festa este ano? Por que? É tão bonita minha festa. Tanta mulher boa, tanto frango, tanta rapariga $[$ risas $]$. Eu estou avisando que vai ter. Que, se não tiver, vou fazer de meu modo. E de meu modo é mais caro."

Habiendo obtenido las promesas y la garantía de la realización de su fiesta, Zé Ferreira se sentó a la cabecera de la mesa, destapó el garrafón de jurema y, ayudado por un par de asistentes, empezó a repartir la bebida en vasos de plástico. Una bebida no demasiado alcohólica en la que se mezclaba el aguardiente, mucho azúcar y un sabor algo terroso que no sabría identificar, seguramente la madera de la jurema que se había dejado macerar en el alcohol (Pedro me habia dicho: "Ahora confunden 'jurema' con 'quentão' - una bebida invernal caliente con cachaça, gengibre, limón y azucar").

Betinho comenzó una serie de cantigas, las primeras estrofas sin ningún acompañamiento, que al entrar las palmas y la maraca se hacen ininteligibles: "A jurema fulorou / vou fazer meu vajucá/ [...]". Minutos más tarde, cambio de ponto: "Quando entrei na jurema / foi sem medo de ninguém/ o caboclo do mar [...]". "Quem tem medo da jurema/ tá na hora de se retirar/ [de arriar]". Inicia entonces una serie de cantigas para boiadero, con el clásico "Xetruê, xetruá" característico de esta entidad en los terreiros de Umbanda. Tras varios minutos de cantar, un grito 
ronco se impone; ha llegado el boiadero de Betinho. Sus primeras palabras: "Salve Nossa Senhora e Jesus... e viva Deus. Salve a ciência divina, salve a Jurema sagrada, salve Zé Ferreira!!!”. Le responde el espíritu incorporado en Dona Maria con una cantiga, con estrofas cortas y muy rítmicas: "E bebe eu e bebe tu,/ e bebe tu e bebe eu". Entona otra más, correspondiente a la solidaridad alcohólica que se establece entre espíritus y personas: "Tomando cana,/ meu guará,/ tomando cana”.

Fin de la cantiga. Zé Ferreira, junto al boiadero, habla de "as mulheres mais bonitas do mundo, eu não gosto de mulher murcha, não". Su compañero empieza otro ponto: "Fui eu que cortei o pau/ fui eu que fiz a jangada/ fui eu que roubei a moça/ trazendo para encruzilhada./ Catimbozeiro medroso/ só fala e não faz nada". Pasa a otro: "Foi num galho de jurema que fui coroado/ foi com um galho de jurema que eu quebrei todo embaraço".

De entre la algarabía empieza a destacarse la voz de Zé Ferreira, conversando con otra mujer: "Se você pensar em ser um catimbozeiro, você vai ser um catimbozeiro mesmo. Tudo o que você pensar, você é. Se você pensar em ser um médico, você vai ser um médico. Tudo que você pensar, você é. Depende muito de você. Se sua mente for fraca...". Su voz es tapada por una cantiga iniciada por Betinho: "A minha lagoa não seca/ quando o medo vem me pegar/ a minha lagoa não seca/ quando meu mestre chegar". Vuelve a una estrofa ya entonada: "Desembaraçando eu venho, desembaraçando eu vou".

Zé Ferreira: "Sem Deus ninguém é nada; mesmo que seja uma coisa pesada, mas sem Deus ninguém é nada. É como numa casa de candomblé, sem Exu ninguém faz nada, não é não?”. Betinho intenta otra cantiga ("Eu entrei de madrugada...), pero Zé lo interrumpe con un gesto y continúa con lo que estaba diciendo "sem Exu ninguém faz nada". Betinho: "É verdade". El espíritu de Dona Maria comienza otro ponto: "Dizeram que esta casa não prestava/ que Zé Ferreira só descia para be- 
ber/ mas eu confio no axé que eu tenho/ que Zé Ferreira nunca fez mal a ninguém,/ disseram se...". El mestre interrumpe la cantiga para que nadie se engañe sobre su sentido:

"Nunca fiz mal a ninguém. Eu sou espírito socializado. Quando é hora de fazer mal, eu faço. Mas, quando é hora de fazer bem, só faço bem, graças a Deus. Eu peço perdão a Deus por algumas coisas que eu já fiz... Algumas coisas que já fiz... Mas mereceu, mereceu. Um menino que te aperreia, se o menino te aperreia, você não dá um tapa no menino? Já teve quem me quis derrubar, quer cuspir, quer afundar na pobreza e se saiu mal. É problema dele, não é não? Não fui eu, fui eu? Eu sou um espírito que não faço mal a ninguém, já cantei."

Termina su alegación con una risa sardónica y Betinho entona una nueva cantiga: "Eu estava no beco na virada do beco/ seu Zé me enganou". A poco, Zé Ferreira inicia otra: "Se soubesse quem eu era/ chorava de alegria/ Ferreira é meu nome/ no meio-dia/ Mas eu me chamei Zé Ferreira/ e o resto vai se danar". La termina pronto y comienza a despedirse:

"Deus e a Jurema sagrada guardem vocês todos; que livrem vocês de tudo quanto é ruim; que dêem a vecês um bom retorno a seu lar; que nunca lhe faltem o pão de cada dia; que os inimigos não possam com vocês. Que a força da minha Jurema Sagrada, neste mês tão poderoso [agosto], que dê a vocês tudo o que vocês querem e principalmente os que tiver coragem de pedir. Que os pensamentos sejam fortes, e que seja alcançado tudo aquilo de bom. Que a minha mãe Maria Santíssima faça de teus filhos bons filhos, que nunca se envolvam com isso ou com aquilo, que nunca passem a fumar munturu [marihuana], que nunca passem a tomar injeção, que nunca passem a se envolver com gente que não presta. Que a minha Jurema Sagrada 
Revista de Antropologia, São Paulo, USP, 2005, v. 48 no 2.

guarde todas essas crianças que estão crescendo, que faça de você um bom marido, que eles nunca partam para bater ou pra maltratar. Louvado seja Jesus Cristo! Que o pão de cada dia seja tão grande que dê pra você e pra quem chegar na sua casa. Que as doenças e febres nunca cheguem ao lar de vocês. Que aqueles que querem te roubar, aqueles que querem te matar, que eles sejam destruídos, que destrua aqueles que querem matar você.”

Tras estas declaraciones generales, el espíritu se dirige a nosotros de una manera personalizada, deseándonos a cada uno paz y felicidad, pero también la recuperación de la salud perdida de una mujer, que el marido de otra encuentre pronto empleo, etc.; en mi caso, un buen retorno a Brasil.

"A cada um dos que participaram dessa reunião, muito obrigado por terem vindo. Que dê a minha matéria muitos anos de vida, louvado seja Deus. Louvado seja o nosso senhor Jesus Cristo...” Acomete otra cantiga: "O que linda palmeira o que lindo palmeral/ onde os passarinhos choram/ quando mestre Zé Ferreira vai embora/ se despede / a jurema me chama eu já me vou/ Zé Ferreira não vai embora”. Y otra más: "A Jurema me chama/ eu já me vou/Zé Ferreira não vai embora”. El espíritu se retira en un temblor del cuerpo de su caballo; Dona Maria inmediatamente vuelve en sí y se suma a la cantiga.

El boiadeiro de Betinho lanza un sonido entre el estertor y la carcajada, y en seguida: "Viva Deus! Salve a Jurema sagrada!”. Se despide: "Boa-vinda e boas-tardes...”. Y sigue: "Quem pode mais do que Deus? Viva Deus! Louvado seja o Nosso Senhor Jesus Cristo! Salve a Jurema sagrada! Que a paz de Deus siga como todos vocês!". Y se embarca en una bendición general similar, pero más breve, que la que nos había ya hecho Zé Ferreira.

Dona Maria, ya sin su mestre Zé Ferreira, da por terminada la ceremonia. "Eu queria agradecer a Deus e aos bons espíritos por nossa 
reunião. Mas eu confio que tenha sido de proveito para mim e para todos aqueles que vieram até aqui. Que Deus lhes dê paz, sossego, saúde e tranqüilidade. Obrigada às pessoas que vieram aqui pela primeira vez... Não sei se agradei, que a gente nunca agrada, né?" Comienza con una oración católica y después con otra umbandista que son respondidas a coro por los asistentes. Finalmente, el himno de umbanda ("Umbanda é paz e amor...").

Por último: "Que Deus Todo-Poderoso dê por encerradas as nossas correntes. Desculpem se não gostaram de alguma coisa”.

Nos condujeron a un pequeño patio trasero; un par de mujeres improvisó una mesa sobre la que depositaron unas fuentes con ensaladilla, farofa de Exu (harina de mandioca frita con tropezones) y poca cosa más. Comida sin duda insuficiente para tantos como éramos, repartida apresuradamente en platos plásticos que pronto vaciamos. Hicieron aparecer también unas cuantas botellas de cerveza y algunas más de refresco que tampoco duraron mucho.

Betinho se me acercó: "Quería decirle algo, pero debe quedar entre nosotros, debe morir aquí". Así comenzó lo que no era más que un pedido de dinero "para a festa do Mestre", que tanto gasto significa. Mientras yo buscaba qué darle, repetía una y otra vez "cualquier ayuda sirve", que siguió repitiendo cuando le alargué un billete de 10 reales, unos 5 euros en la época, mientras embolsaba no muy satisfecho el escaso botín. De un pedido semejante, lo sabría más tarde, pero por boca de Zé Ferreira incorporado en Dona Maria, había sido objeto M. do C., quien, mucho más generosa que yo, había hecho entrega de 50 reales. Ese había sido el motivo de que en medio de la ceremonia el Mestre la hubiese hecho entrar en el pequeño recinto de detrás de la mesa. Pero de eso me 
enteraría al día siguiente; ahora correspondía desalojar poco a poco la casa, montarnos a nuestros coches y volver a nuestra civilización, unos pocos quilómetros más céntrica que ésta.

Tiempo después, en una nueva visita a Recife, participaría de otra de estas incursiones, punto final de un seminario sobre Roger Bastide en un congreso de la Asociación Brasileña de Antropólogos. Ni grabación, ni fotografías, ni notas tomadas en el momento me ayudan ahora a reconstruir esta experiencia.

Salvo quien nos conducía y yo mismo, los nueve integrantes del grupo eran distintos: un profesor francés especialista en Bastide, una doctoranda española cuya investigación nada tenía que ver con las religiones de posesión, además de profesores y doctorandos de cuatro universidades brasileñas. Íbamos en dos coches, uno de nuestro cicerone, el otro puesto a nuestra disposición - con conductor incluido - por el Tribunal Federal Regional de Justicia, que había financiado nuestro seminario.

Se había acordado un encuentro junto al Mercado de Agua Fría a las 19.30 y, contra mi escepticismo, minutos después de la hora convenida apareció, acompañado por el contacto de nuestro guía, Edivaldo, el mestre a cuya casa estábamos convocados. Un muchacho delgado y pequeño, con un rostro bien dibujado, un bigote muy fino sobre una dentadura tan perfecta como pequeña; sus ropas blancas ocultaba la fuerza de un cuerpo que pronto veríamos más descubierto.

Otro corto desplazamiento en los coches, en un trayecto irreproducible, terminó en una estrecha calle de barro. Una casa que daba al exterior por un patio minúsculo y caótico. En la entrada, un par de muchachas, vestidas como para un baile - estábamos en plenas fiestas juninas - con un hombre mal vestido y sin afeitar. Un pasillo estrecho por el 
que llegamos al cuarto de la ceremonia: tres lados ocupados por bancos y sillas en los que cabíamos malamente y la mesa en el último, con la parafernalia habitual: los vasos con agua - las princesas -, botellas de cerveza, rollos de tabaco, pipas, flores, algunas estatuillas. Edivaldo nos enseñó las principales: en un extremo, Maria Luciara da Conceição, una bella gitana de yeso pintado sobre cuya cabeza había un pañuelo en el que se veían unos billetes que aumentarían después con nuestra contribución; en el otro, un niño negro desnudo, Malunguinho.

Sobre la mesa, una foto antigua mostraba a una mujer vieja acompañada por un hombre. Esa mujer era, dijo Edivaldo, una gran catimbozeira de Recife, su mãe de santo en el candomblé; era Dona Lidia, en verdad mãe de santo del sacerdote del candomblé con el que trabajo desde 1984 (en cuya casa de São Paulo estoy escribiendo estas líneas, hoy, 3 de julio de 2004). La edad de Edivaldo hacía imposible esta filiación; hasta que tuviese algún grado de entronque con esta línea resultó después en extremo dudoso: al consultar sobre este muchacho a un nieto carnal de la sacerdotisa y cabeza visible en la actualidad del linaje, éste no lo conocía ni sabía quién podía ser.

Las muchachas y el hombre se turnarían en distintas acciones de asistencia al "trabajo". La primera, la "defumação com as ervas da jurema", como dice la cantiga umbandista que todos cantamos de pie, acompañando con las palmas. Uno tras otro, fuimos pasando sobre el pequeño recipiente en el que ardían las hierbas e hicimos gestos como de estar bañándonos con su humo. En seguida, Edivaldo inició otra cantiga y con un temblor de su cuerpo, dio paso al espíritu del mestre José Floriano, al que una de las muchachas ayudó a quitarse la camisa y colocarse el sombrero de cuero típico del personaje. Más y más cantigas, oraciones católicas que tuvimos que rezar puestos de pie y dándonos las manos en una cadena espiritual típica del kardecismo. 
El mestre mostraba su contento por nuestra presencia en su roça; los beneficiarios principales de su satisfacción eran el profesor francés y nuestro guía, a los que pronto daría un tratamiento especial: al primero le pediría en público - traducido por una de las profesoras - que fuese el padrino de la casa, al segundo, lo llevaría aparte para - lo sabríamos más tarde - pedirle una contribución económica especial.

No éramos los únicos asistentes a la sesión. Un par de mujeres entraron en el cuarto para hablar con el mestre y después se retiraron a la pequeña entrada de la casa, ya que nosotros ocupábamos todo el espacio ceremonial. Al poco rato, se sumó un negro con barba blanca, imagen perfecta de preto velho, al que le faltaba la pierna derecha; su único pie, calzado en una chancla, estaba hinchado y deforme. Era el asistente principal de Edivaldo; empuñó la maraca que él mismo había traído - el mestre había pedido minutos antes de comenzar la sesión que lo llamasen para que la trajese -, y entonó las cantigas que comenzaba Zé Ferreira o a veces era él quien las comenzaba y el espíritu quien las seguía.

El desempeño del Mestre Zé Floriano giró más que nada alrededor de una serie de botellas de cerveza que cogía de la mesa, le eran abiertas por alguna de sus ayudantes $y$, tras haber bebido unos tragos de ella $-y$ de convidarnos a nosotros -, se la vertía por la cabeza y el cuerpo, tras lo que una u otra de las muchachas acudía con un paño de cocina para secar el suelo y, a veces, con una toalla para secar al mestre. Junto a las botellas y las cantigas, una prueba de fuerza que ya había yo visto en algún terreiro umbandista: el espíritu incorporado hace que alguien se ponga espaldas a espaldas con él, lo coge con sus brazos por los codos, baja un poco sus piernas y con un impulso lo alza sobre su columna, dejándolo con los pies balanceando en el aire. Cuanto más grande el individuo al que así se manipula y cuanto más pequeño el "caballo", más evidente es la presencia espiritual que multiplica las fuerzas de éste. En este caso, la pequeñez de Edivaldo era engañosa, porque su cuerpo 
era enjuto pero musculoso. Sin embargo, tras haber hecho este número con uno de los profesores nativos y con una de las mujeres, Zé Floriano la emprendió con el investigador francés, cuyo peso al menos duplicaba el de su caballo. Para alivio general, el espíritu logró la proeza, que repetiría en una segunda aparición.

Zé Floriano comenzó a manipular unas botellas plásticas de CocaCola con un líquido vinoso - la jurema; su asistente le abrió una, casi vacía y el espíritu empezó a beber con ansiedad mientras el líquido le chorreaba por la cara. Aparecieron unos vasos de plástico, y el espíritu hizo el amago de llenarlos de la botella, pero el ayudante abrió otra y fue de ésta, que no había pasado por la boca y las babas de Edivaldo, de la que finalmente seríamos servidos. Otro elemento clave del catimbó fue puesto en acción, la larga pipa de angico que, apenas encendida de la manera normal es invertida para, apoyando la boca en la cazoleta y soplando, expulsar una línea de humo por la boquilla que Zé Floriano pasó por diversas parte del recinto.

Una de nuestras compañeras, que había mostrado bastante conocimiento de las cantigas umbandistas entonadas y que las había cantado con entusiasmo y arte, se levantó del banco en el momento en que el espíritu anunció su partida para explicarle que en los próximos días iba a sufrir una operación de un pie y que quería que diese su apoyo espiritual para que la intervención tuviese éxito. Nada podría haber satisfecho más al espíritu, que se apresuró a coger un puñado de yerbas y comenzar con ellas a aplicar un fuerte masaje en el miembro enfermo y a echarle humo de la pipa; una larga operación ritmada con cantigas en las que destacaba la voz de la profesora.

Al tiempo, el espíritu dio por terminada su cura (la paciente afirmó sentirse mucho mejor). Era hora de que los visitantes asistiésemos al desempeño de otra entidad, Maria Luciara da Conceição, cuya imagen sobre la mesa se nos había enseñado, pero la crisis del pasaje de un espí- 
Revista de Antropologia, São Paulo, USP, 2005, v. 48 no 2.

ritu a otro en el cuerpo de Edivaldo fue todo menos tranquilo. Saltos, agarrotamientos, caídas que fueron a penas contenidas por las dos muchachas y alguno de nosotros. El torso desnudo del mestre debía convertirse en el torso cubierto de la mestra y una de las muchachas le ató un paño con un nudo por la espalda. El rostro de Edivaldo pasó de la hosquedad sarcástica de Zé Floriano a la lascivia de Maria Luciara; su minúsculo bigote volvía el cuadro desconcertante.

El asistente de Edivaldo entró en trance: un preto velho se incorporó en el viejo negro. La enferma del pie se le aproximó para conversar con la entidad. Mostrando una vez más su dominio del código umbandista, lo trataba con gran dulzura, se dirigía a él como "meu pai” y "o senhor", se interesaba por que estuviera cómodo durante su presencia en tierra, entonó una cantiga en su homenaje; la observadora se había convertido en observable.

Maria Luciara no bebía cerveza, sino "champagne", una sidra artificial barata, que quiso compartir con nosotros, repartiéndola en los mismos vasitos plásticos en los que habíamos bebido la jurema; también cogió unas pequeñas manzanas y una flores y nos las fue dando con sonrisas impúdicas. Mientras tanto, las muchachas de la casa entonaban cantigas de pombajira. La sesión no duró mucho; el contacto que había acompañado a Edivaldo a nuestra cita, advirtió que estábamos llegando a la hora que él se había comprometido a que la ceremonia terminase, las 10 de la noche; el espíritu apresuró su partida.

Volvía el mestre Zé Floriano, tras una crisis similar a la anterior, que obligó a que las muchachas, ayudada por el negro viejo que ya había vuelto en sí, se esforzasen en mantener el equilibrio del caballo que cambiaba de jinete. Llegó advirtiéndonos que sólo venía para despedirse de nosotros, aunque se demoró un tiempo insistiendo en nombrar al profesor francés en padrino de la casa y recibir nuevamente su aceptación traducida por alguno de nosotros y hacerle una vez más la pirueta que 
antes he descrito. Cantigas de despedida de la entidad; nueva crisis, Edivaldo volvía a ser Edivaldo, cierre de los trabajos con el himno de umbanda, todos de pie, enlazando nuestras manos en cadena espiritual.

Pocos trámites para salir de la casa; fundamentalmente uno: depositar cada una de las visitas académicas 20 reais (6 euros) en el pañuelo sobre la imagen de Maria Luciara, cifra que nuestro guía sugirió como razonable. Edivaldo quiso tener una entrevista personal con el profesor francés - siempre con la mediación de un intérprete; la promesa de su patronazgo debería ser concretada. Después, rápidas despedidas, agradecimientos de unos a otros, amontonamiento en la calle del grupo de excursionistas para dividirnos entre los coches. Regreso en coche oficial a un hotel de cuatro estrellas.

\section{Conformación del campo religioso}

Son diversas las líneas de análisis que pueden seguirse a partir de estas descripciones; las que yo he elegido están subordinadas a un eje, el de la conformación del campo religioso. Campo complejo al mismo tiempo que altamente sistemático, una red, en la que los distintos integrantes guardan entre sí relaciones de simetría e inversión - cuando no de metaforización (Giobellina Brumana y González Martínez, 1991 [1989], p. 85-90; Giobellina Brumana, 1994); lejos está el actual campo religioso de cualquier ciudad brasileña del caos poliforme que retrataba para el Rio de Janeiro de fines del XIX, el periodista João do Rio:

[...] a cidade pullula de religióes. Basta parar em qualquer esquina, interrogar. A diversidade dos cultos espantar-vos-a. São swendeborgeanos, pagãos literarios, physiolatras, defensores de dogmas exóticos, auctores de reformas da Vida, reveladores do Futuro, amantes do Diabo, bebedores de 
Revista de Antropologia, São Paulo, USP, 2005, v. 48 No 2.

sangue, descendentes da rainha de Sabá, judeus, schismáticos, espíritas, balaos de Lagos, mulheres que respeitam o océano, todos os cultos, todas as crenças, todos os Sustos. (1906, p. 7)

Las dificultades para historiar el pasaje entre este panorama y el actual son totales; carecemos de documentación, son muy escasos los registros de testimonios, hay enormes áreas de la religiosidad subalterna que no gozaron en su momento del interés de los estudiosos etc. De todas maneras, hay ciertas hipótesis que pueden sustentarse con base tanto en datos empíricos como en la realidad estructural del objeto. Esta cuestión diacrónica, sin embargo, me interesa menos desde el punto de vista histórico que desde el de la naturaleza de la religiosidad subalterna y de las lógicas que la rigen.

Ahora bien, en todo caso, el término "sincretismo" ha sido con frecuencia empleado a la hora de referirse a la religiosidad brasileña. Siempre había tenido yo reparos a esta utilización ya que me parecía que implicaba una diferencia entre religiones "puras" y aquellas producto de la mezcla de elementos preexistentes. Entiendo ahora que lo que daría al término "sincretismo" un valor interpretativo más sólido y haría útil su empleo, no es la idea de mezcla - de la que ninguna religión está libre -, sino de la naturaleza de tal mezcla, de su orientación. Calavia (1996, p. 115) apunta en este sentido: el carácter salvaje del pensamiento subalterno, la polisemia insalvable de sus términos, el libre pasaje entre nociones nunca formuladas de manera unívoca, en fin, su carácter de bricolaje que ensambla, según una lógica propia y original, elementos antes regidos por otra lógica.

Hablar así de sincretismo, entonces, es hacerlo ante todo de un procedimiento de apropiación de elementos de cultos eruditos, desde un espacio religioso subalterno y en término de su propia lógica y necesidades simbólicas. Es el bricolaje, en el sentido de una construcción ágrafa 
o semiletrada de un cuerpo con piezas más o menos dispares provenientes de sistemas letrados coherentes. Es decir, lo que pongo como punto de partida de esta idea de sincretismo es un corte dentro de una topología social que implica un "arriba” y un "abajo”. Se distancia así este empleo del que opera, por ejemplo, al hablar, como lo hacen los historiadores de las religiones antiguas, del "sincretismo gnóstico". De esta segunda manera, se piensa ante todo en diversas formas de síntesis, uniones, yuxtaposiciones, fusiones, etc., que existen en todas las religiones, y, por lo tanto, "sincrético" sirve así para denominar a cualquier culto, y carece entonces del valor heurístico que en nuestro caso exige; se piensa además en un juego entre eruditos, textos e hipertextos, que poco o nada se dieron en los orígenes de los cultos populares brasileños.

Apropiación subalterna de una producción erudita que no excluye el canibalismo entre producciones subalternas, sino que, por el contrario, la supone y la posibilita. Vayamos a un ejemplo clave. La formación de los distintos cultos "afro" en Brasil se llevó a cabo, a mi entender, con la consolidación de un sistema polinómico, un sistema de tipo totémico, que unía en un solo panteón, en un solo templo y bajo la autoridad de un solo sacerdote, lo que en África se presentaba como cultos autónomos de divinidades independientes en diversas localidades extendidas en un vasto territorio, prácticas místicas dispares (adivinación, sacrificio, herboristería, iniciación, etc.) en manos de agentes diferenciados.

Esta fusión, es mi conjetura, se hizo - la hicieron africanos y descendientes de africanos en Brasil, en las ciudades brasileñas - siguiendo un modelo provisto por la iglesia católica. Estamos pues lejos de las racionalizaciones nativas, tomadas por buenas por observadores ingenuos como Bastide, según las cuales los negros ocultaban astuta y temerosamente sus dioses de origen tras una imagen católica. El catolicismo no era un escollo al desarrollo del candomblé, sino en buena medida un cauce y una matriz; lo que sólo pudo darse porque ambas tradiciones compar- 
tían una misma sintonía. Esto se nos vuelve patente por la similitud de la devoción a los santos y la que los africanos habían tenido con sus divinidades y espíritus, el carácter clasificatorio que unos y otros muestran frente a problemas y a favores, la relación clientelística entre fieles y entidades. Por otro lado, la idea misma de un templo en el que conviven los orixás que en tierras africanas viven separados, si se me permite tamaña especulación, ¿no parecería provenir de la Iglesia que como templo, como edificio material, alberga siempre diversos miembros del panteón católico?

Otra cuestión, en el mismo sentido: el que Cuba y Brasil hayan procesado síntesis similares dentro de la raíz africana así como entre los elementos de ésta, los provenientes del catolicismo popular, los de origen en la hechicería ibérica y el bajo continuo del espiritismo llegado de Francia. La coincidencia de composición y de dirección de ambas formaciones religiosas refleja, a mi entender, que la amalgama que en un caso y otro se ha producido indica una suerte de masa crítica que la ha permitido. Mi hipótesis - mejor, una vez más, mi especulación conjetural - es que el factor desencadenante de esta recomposición radical del campo religioso ha sido la presencia del espiritismo europeo, en cuanto legitimante erudito de la posesión como mecanismo de contacto con las entidades místicas, de su presencia entre los hombres, de su devoción, de la manifestación de sus poderes. Câmara Cascudo (1988 [1934], p. 95) advertía del efecto multiplicador que había tenido la inserción del kardecismo en las prácticas de los cultos de posesión: "Nas Macumbas de outrora, quando o elemento indígena preponderava espiritualmente, o transe só attingia ao Mestre. Só elle recebia as comunicaçóes do Além, receitava e distribuia noticias dos ausentes. $\mathrm{O}$ baixo espiritismo nivelou a virtude mediúmnica”.

Pero, me permito insistir, ha sido la devoción católica, creo, lo que ha brindado a las nuevas religiones americanas de raíces afro buena par- 
te de las categorías y de las denominaciones con las que operan. Los orixás y orichas son ángeles de la guarda, santos, vírgenes y hasta el propio Jesús - lo que no eran del otro lado del Atlántico - en la medida en que han superado su carácter regional para converger en templos únicos como un panteón articulado, con la fusión en un solo agente de las diversas clases de sacerdotes, adivinos, hechiceros, yerbateros, etc., diseminados por tierras africanas.

El referente católico, su panteón, no es un ingrediente circunstancial de santería y candomblé, o una mera astucia que ocultó un culto prohibido bajo ropajes aceptables, como la astuta ideología nativa tomada por buena por el ingenuo Bastide pretendía. Mucho más que eso, es el indicio de una misma devoción, de una práctica equivalente con lo sagrado, de una concepción similar del vínculo con el mismo; Alfred Metraux, René Ribeiro, Roberto Motta son algunos de quienes han disuelto las ilusiones ideológicas de lo afro-resistente.

\subsection{Las agencias}

Una de las perspectivas desde las que se podría abordar el material descriptivo presentado es la de las propias agencias, su organización interna, jerarquía, establecimiento interno de espacios de poder, surgimiento eventual de liderazgos alternativos, contradicciones - traducibles y resolubles o no en un plano místico; su capacidad de atraer y reclutar a clientelas y fieles, el prestigio o la ausencia de él en relación a la cuestión clave de este tipo de oferta religiosa: su capacidad de dar cuenta de la aflicción (o de provocársela a otros). En fin, el tipo de problemática que en mis trabajos sobre el candomblé y sobre la umbanda he desarrollado con gran atención y que, por ahora, dejo en el aire en relación al catimbó. De hecho, poco o nada de lo que aquí he registrado apunta en esta dirección. 
Revista de Antropologia, São Paulo, USP, 2005, v. 48 № 2.

De todas maneras, los casos descritos representan polos opuestos y sirven para ver el amplio arco en el que se mueven sus agencias y agentes. La jurema de Dona Maria se lleva a cabo en un centro independiente a su domicilio - aunque esté junto a él -, de buena construcción, amplio, limpio y ordenado, con una capacidad de convocatoria en su entorno inmediato que atrajo a una decena de vecinos al iniciar una sesión no programada. Edivaldo, por el contrario, realiza sus ceremonias en un cuarto de su casa, pequeña, desvencijada, no demasiado aseada. Mientras que en el primer caso se veía una organización clara y un personal que hasta llevaba ropa uniforme, en el segundo nada de esto existía: las muchachas que ayudaban materialmente a Edivaldo vestían de una manera en absoluto acorde con la ocasión y no intervinieron en el ceremonial, salvo en las ocasiones en las que se nos pidió darnos las manos para formar una cadena espiritual. Por último, la edad de Dona Maria, así como su compostura, su forma de tratar a propios y ajenos, su ductilidad ceremonial, eran la de una "senior", mientras que todo en Edivaldo lo mostraba como un "junior" en sus primeros escarceos en busca de establecerse.

En el continuo espiritualista ${ }^{2}$, Dona Maria es alguien conocido y significativo. Había sido invitada, y había comparecido, a una asamblea convocada por Intecab ${ }^{3}$ en el Sitio de Pai Adão en junio de 2004, de la que pronto hablaré, con un puñado de pais y mães de santo del candomblé, la elite religiosa con la que se mueve el mundo académico y el político-administrativo. Edivaldo, ya lo he dicho, ni siquiera era recordado por Papai, la cabeza de la línea a la que aquél decía pertenecer; su presencia en esa reunión hubiera sido sorprendente.

Otra cuestión es la de la inserción de las agencias religiosas en su entorno, del juego de reciprocidades de todo tipo que se establece con otros actores sociales, culturales, económicos, políticos locales, barriales, "del pedaço" $\mathrm{y}$ hasta con instancias que superen este ámbito inmediato. Los 
"observables" evidentes de este plano se registraban sólo en casa de Dona Maria: eran las banderolas del maracatu y el agrado con que nos los mostró y abundó sobre ellos. De su templo salía un maracatu, un conjunto carnavalesco con decenas de bailarines, lo que lo convertía en un punto estratégico para los habitantes del barrio y, al mismo tiempo, en foco de subvenciones estaduales, municipales y privadas, correlato sin duda de un cierto poder político, significativo a la hora de las elecciones y de un eventual apoyo a tal o cual partido político. Otro observable, también en casa de Dona Maria, que nada al respecto dijo y que, por lo tanto, quedó en segundo plano: las decoraciones de las paredes que hacían saber que ese espacio era en otras horas guardería infantil.

Una última cuestión, que une las dos primeras, es la de la mediación con las masas de fieles que las casas estables, además de las federaciones y demás organismos de representación de las agencias religiosas, pueden significar para instancias del "centro". Esta mediación puede asumir rasgos muy diferentes, como el de la incierta capacidad de reclutar votos en las elecciones. Pero hay otros lazos no depredatorios, en los que hay un beneficio evidente para los seguidores de los cultos populares, como las campañas de prevención contra el Sida.

Un caso del que he sido testigo es la ya referida reunión convocada por Intecab en el Sitio del Pai Adão. Este encuentro, programado como una "jornada de hojas", tenía como objetivo central el que dos funcionarias del ayuntamiento de Olinda expusiesen la situación de una pequeña reserva forestal ubicada dentro de los límites de la ciudad (Mata do Passarinho), cuya supervivencia está en peligro a causa de las ofrendas allí depositadas.

La reunión, alguien lo diría en algún momento, era un fracaso. No llegábamos a la docena de asistentes, entre los cuales el profesor francés y un colega brasileño - llegaron por su cuenta cuando la sesión había comenzado -, a pesar de que se había convocado a mucha más gente. 
Un domingo por la tarde y en medio de una lluvia que no paraba desde hacía una semana, los ausentes habrían encontrado una ocupación más gratificante. Ocupábamos - es un decir - el salón del Sitio; alrededor de una mesa, quienes iban a hablar: Papai, y tres mujeres - una dirigente regional de Intecab y dos funcionarias del ayuntamiento. En un semicírculo, el puñado de asistentes.

La sesión fue iniciada por Papai con unas breves palabras sobre la finalidad del acto: un encuentro con representantes municipales para discutir cuestiones de beneficio común relacionados con los vegetales, uno de los centros neurálgicos del culto de los orixás. Enseguida, entonó con su bella voz una serie de cantigas de hojas, las canciones destinadas a la manipulación de los vegetales, a coger las hojas, a cortarlas, a mezclarlas, a aplicarlas... Todos de pie en signo de respeto. Finalizada esta parte más religiosa, comenzó el debate. Presidía la reunión una joven mulata, licenciada en ciencias de la educación, miembro de la dirección de Intecab-Pernambuco, que habló sólo para presentar a las funcionarias del ayuntamiento. Éstas venían a pedir que la entrega de ofrendas en la "mata virgem", es decir, la reserva forestal en la que trabajaban, siguiese un cierto orden. En síntesis, la cuestión se planteaba en los términos de un pequeño documento que habían repartido entre los asistentes a la reunión:

Uma reflexão para melhor entendimento dos trabalhos, despachos, oferendas e outros rituais realizados na Mata

Vamos conciliar o relacionamento entre o sagrado e o profano, evitando aborrecimento e conflitos desnecessários, realizando culto, oferenda e trabalhos em perfeita harmonia com o ambiente da Mata e as comunidades que frequientam as áreas verdes de preservação, tudo isto em equilíbrio e sintonia para que os dois lados só se beneficiem. 
En términos concretos, las recomendaciones eran que no se empleasen plásticos y vidrios, que se tuviese el máximo cuidado con el fuego de las velas o de la pólvora utilizada en los trabajos, y que no se depositasen las ofrendas en cualquier sitio, sino en aquellos que los cuidadores de la mata habían destinado a ese uso. La discusión que tuvo lugar tras la intervención de las mujeres, entablada con la mejor voluntad, mostró las dos caras de la cuestión.

Por un lado, el principio general de que para los cultos que empleaban la mata su mantenimiento era esencial, no sólo por no destruir un espacio necesario para los rituales, sino por una cuestión ideológica esencial: el respeto a la naturaleza (la Naturaleza) con su potencia mística, el axé. Por el otro, la imposibilidad de que las acciones de los Orixás fuesen regidas y unificadas por criterios ajenos; si un santo quiere recibir su ofrenda debajo de tal árbol, no se le puede contrariar. Pero además de toda consideración, había otra en la que alguno de los presentes hizo énfasis: ¿cómo vamos a impulsar estas medidas si nuestra capacidad de convocatoria es tan poca que hoy somos cuatro gatos? El par de horas que duró la reunión no hizo más que girar sobre estas consideraciones; a su término, nadie sabía decir si serviría para algo.

Entre la visión teológica abstracta de la prioridad de la Naturaleza y la realidad concreta de agencias de culto con autonomía absoluta, de la inexistencia de un centro y de una jerarquía, lo que quedaba era la posibilidad del ejemplo y de la prédica. ¿¿Hasta dónde ésta puede tener éxito? Algunos de los objetivos, pienso, son más viables que otros. Así, cambiar los recipientes plásticos por hojas puede seducir a mucho sacerdote, pero eliminar botellas y vasos parece más dificultoso, ya que forman parte de los emblemas de exus y pombas gira, y concentrar todas las ofrendas en unos pocos metros cuadrados, creo, está condenado de antemano al fracaso. Pero cualquiera que fuese el resultado de esta iniciati- 
Revista de Antropologia, São Paulo, USP, 2005, v. 48 no 2.

va "erudita", se establecía en un paradigma diferente al que normalmente ha regido la relación entre unos y otros.

Veamos otro tipo de vínculo, correlativo a la transversalidad social y cultural de los cultos subalternos. En casa de Edivaldo, una de las profesoras pedía y obtenía los servicios del espíritu en tierra para cuidar de su pie enfermo. Esta relación de eventual cliente de agentes subalternos es diferente, a mi entender, de la conversión religiosa que unos cuantos estudiosos del candomblé han experimentado. No se trata, como entre éstos, de atravesar el espejo y canibalizar al objeto de estudio - o ser canibalizado por él, tanto da -, sino de mantenerse en su propio lugar y establecer vínculos puntuales con agentes, según las propias necesidades.

Un caso extremo, en el que estuve envuelto de manera indirecta, es el de una antropóloga que suponía haber sido objeto de una acción de hechicería por parte de una catimbozeira a quien había irritado por su arrogancia (versión de la agente) y que acudió a otro agente, un pai de santo (versión de este segundo agente), para deshacer los efectos místicos, una serie de muy graves desarreglos de salud (versión de la tal profesora). La acción desembocó "na calada da noite" en una sala universitaria, con la académica y un subordinado suyo siendo objeto de un "descarrego", un ritual del candomblé en el que se rasga las ropas del cliente, se le pasa una gallina por el cuerpo que después se hace reventar contra el suelo (frango de estouro), se le rompen huevos en la cabeza, se le echa palomitas por todo el cuerpo, entre otras cosas (versión horrorizada del subordinado). Fui, por último, testigo de una conversación entre la catimbozeira y el pai de santo, en la que éste se excusaba ante aquélla - que aceptó las excusas - de haber deshecho su acción de hechicería: la vieja amistad que lo unía con la profesora lo había obligado (sin contar el dinero que habrá recibido por el ritual, como es natural). 


\subsection{Itinerarios en el campo}

Otro de los aspectos es algo compartido como es obvio por ambos agentes: nuestra propia presencia en sus casas, nosotros provenientes de altas instancias académicas, con la mayor distancia social y geográfica con el ámbito que visitábamos. Este último observable es muy complejo; indica la relación entre los centros eruditos y las agencias religiosas subalternas, por un lado, y, por otro, las relaciones entre agencias de mayor o menor porte, estabilidad, legitimidad, prestigio, etc.

Nuestra presencia en casa de Edilson implica que, teóricamente, aun los pequeños grupos más o menos efímeros que no llegan a constituirse como agencias consolidadas pueden tener su investigador, exclusivo o compartido con otras "casas", o al menos ser detectados desde agencias más poderosas por las relaciones de clientelismo o de visita ${ }^{5}$ que mantienen con frecuencia. Pero si quizás existe una suerte de continuo que permite recorrer el mapa nunca trazado de los centros religiosos, no todos los trayectos son indistintos; están los a favor de la corriente; están los en contra de la corriente.

Pienso más que nada en los itinerarios que siguen los investigadores, la mayoría de las veces alumnos de cursos de maestría y doctorado. La impresión que tengo es que éstos entran en campo por la puerta abierta de los centros tradicionales, con los que las instancias académicas tienen trato antiguo, y que se mueven en un círculo muy cercano a aquéllos; el que la incursión a casa de Dona Maria hubiese comenzado en el Sitio del Pai Adão es una buena prueba.

No representa esto gran novedad respecto a mi experiencia en São Paulo, iniciada hace más de 20 años. Por lo que pude ver entonces, los investigadores se movían en un circuito de relaciones establecidas entre profesores de la USP y de la PUC con agentes de la umbanda y el candomblé. Entre 1982 y1983, asistí a una mesa redonda en el auditorio 
Revista de Antropologia, São Paulo, USP, 2005, v. 48 no 2.

de la Folha de S.Paulo y a una actividad realizada en el Museu de Imagem e Som, en la que se sucedieron películas, conferencias y coloquios. El plato fuerte, para mí, era la presencia de pais de santo como el Pai Dudu, que me hacían morir de envidia al compararlos con la mitómana semianalfabeta con que yo trabajaba en ese momento. Como doctorando de la Universidad de Uppsala, mi marginalidad respecto al medio académico brasileño hizo que no me sirviese de estas instancias para insertarme en campo, y cuando comencé a relacionarme con profesores la USP o de la PUC - donde seguí un magnífico seminario de Carmen Junquera sobre Lévi-Strauss - ya tenía un espacio propio, obtenido de manera fortuita, que, aunque en ese momento me pareciera tanto menos atractivo que aquel en el que trabajaban mis colegas nativos, ya me había absorbido emocional y profesionalmente.

En mi trabajo encontré varios agentes muy marginales, alguno que operaba entre las camas del dormitorio único de su chabola, otro que lo hacia en la cocina de una choza destartalada, etc.; en un grupo poco más sólido estuve integrado más de un año, hasta la muerte de su jefa. Entonces, en el radio donde me movía - en el par de años de mi trabajo de campo conocí una decena de agencias en un grado más o menos alto de familiaridad - era yo el único elemento "erudito" - y tan exótico como el investigador sueco que entonces era - a no ser la relación que Moacyr Jorge, el periodista especializado en cuestiones espirituales de Notícias Populares, mantenía con el centro de mayor entidad con el que trabajé. De manera correlativa, el desconocimiento que mis "observados" tenían de ese supuesto lugar central mío era lo suficientemente grande como para que la categoría de "fotógrafo" les resultara más prestigiosa a la hora de presentarme a extraños, o que pusieran por encima mío en la escala social a un abogado salido de una dudosa universidad privada. De hecho, el máximo honor que recibí en mi investigación sobre la umbanda fue mi nombramiento como presidente de la sociedad 
civil de un tambaleante terreiro de favela, debido más que nada, a que era propietario de un coche (que el pai-de-santo pensaba, erróneamente, que iba quedar para él cuando yo me fuese de Brasil).

No obstante, fue siguiendo esas redes como llegué a casa de Toninho, el pai-de-santo en cuya casa de candomblé realicé lo central de mi investigación sobre este culto desde 1984. Toninho no tenía por sí mismo vínculos con el medio universitario cuando lo conocí, aunque los tenía de manera indirecta pero inmediata: había sido iniciado por Dona Lídia - aquella cuya foto adornaba la mesa de Edivaldo - y Zé Romão, sucesores directos de Adão - en cuyo Sitio empezaba este texto - y por lo tanto con una tradición que había estado en el centro de interés de los trabajos comenzados en los años '20 por los psiquiatras del Servicio de asistencia a psicópatas de Pernambuco y que en la actualidad no sólo sigue siendo objeto de investigación, sino que ha tenido a su personalidad más destacada, Papai, instalado hasta hace poco tiempo en el Departamento de Antropología de la Universidad Federal de Pernambuco. Fue justamente de la mano de este sacerdote, Papai, que "emergí" de campo para ser presentado a una autoridad universitaria pernambucana, que, por así decir, me reintrodujo en él con el primero de los episodios que he contado.

Esto parecería decir que el campo subalterno está internamente lo bastante interconexionado como para que de un punto cualquiera de su topología pueda llegarse a cualquier otro. Pero no significa esto que cada eslabón de este gigantesco continuo este relacionado con cualquier otro; puede haber todo tipo de desconocimiento entre agencias que están puerta con puerta. Una de las primeras veces que llegué por mi cuenta a casa de Papai, en la Linha do Tiro, en su misma calle, unas decenas de metros más bajo, otra casa llena de gente estaba tocando un candomblé en el que el estilo del toque y el de las vestimentas me eran muy extraños; nadie de las varias personas a las que allí pregunté sabía que tenían como vecino a una de las figura claves del candomblé oficial de Recife. 
Revista de Antropologia, São Paulo, USP, 2005, v. 48 № 2.

De todas maneras, pienso que las prácticas religiosas subalternas son poco transparentes a ojos eruditos. Fuera de un entramado que generalmente asume la representación religiosa y política de los cultos populares, sólo un fragmento de la masa de agencias nos es accesible. No significa esto que este entramado de casas antiguas, conocidas y prestigiosas bloquee el tránsito a las más endebles, ignotas y recientes, sino que la propia dinámica entre unas y otras lo dificulta al extremo.

Las redes virtuales de agencias, desde las más antiguas, influyentes y estables hasta las más recientes, frágiles y conflictivas, las líneas que hipotéticamente pueden ser transitadas entre el conjunto de las casas en las que se realizan prácticas religiosas del arco espiritualista no lo son, ya lo he dicho, en todas las direcciones. Un agente de cierta posición $-\mathrm{y}$ de posición cierta - difícilmente encontrará motivos para acudir a una casa en la que no se cumplan unos mínimos religiosos y sociales. Los agentes marginales, la mayoría de los que conocí en mi trabajo sobre la umbanda, son los que no alcanzan este umbral. Para quien haya entrado en campo por las agencias consolidadas, el pasaje a las que están lejos de serlo es improbable. Los lazos que unen el continuum espiritualista pueden encontrarse en lo que he llamado "médium errante" (Giobellina Brumana y González Martínez, 1991 [1989], p. 193) y en las clientelas (id., p. 208-26). Uno y otros se mueven con toda libertad; un día pueden asistir a una ceremonia en un terreiro importante y al otro ir a casa de una mujer que recibe pombajira en una chabola. Son, por así decir, un margen del margen.

Ahora bien, para detectarlos, para poder acompañarlos, para establecer las complicidades indispensables, el investigador instalado en una agencia estable debe mantener la suficiente independencia respecto a sus autoridades. Ninguna muestra de deslealtad respecto a éstas, ninguna 
confidencia sobre movimientos independientes, se establecerá en caso contrario. Aun dentro de la propia casa en la que uno se ha insertado, una estrecha relación con la autoridad vuelve opaco el resto del grupo.

No es esto una característica exclusiva del campo religioso brasileño. La cercanía al príncipe zande, por ejemplo, hizo que a Evans-Pritchard no se le abriera la práctica estigmática de la hechicería. Algo equivalente ocurrió con Metraux, alto funcionario de la Unesco, en Haití. No es frecuente, sin embargo, que los antropólogos se detengan a considerar el acotamiento de su trabajo de campo, la delimitación de sus "informantes". Una excepción es Michel Napaels (1998), quien nos abre los avatares de su investigación sobre cuestiones de propiedad de tierras entre los canacos. En su caso, la familiaridad con algunos miembros de la aldea no sólo "encerraba al etnógrafo en una red particular" (id., p. 190), sino que lo convertía en presa eventual de acciones violentas por parte de otros miembros con los que los primeros estaban enfrentados.

Otra cuestión: La presencia de investigadores en una agencia se convierte para ésta a menudo en un mecanismo de obtención de legitimidad y prestigio; ¿̨hasta dónde la conciencia de ser foco de atención académica no influye en sus agentes?; ¿̨hasta dónde no pueden provocar modificaciones en lo que hacen y en lo que dicen? O, por el contrario, ¿hasta dónde la presencia del observador no congela la dinámica religiosa? ¿Hasta dónde no se repite en un plano más amplio, en muchos más centros de culto, lo que debió ocurrir en las distintas etapas de la investigación de los cultos afro por eruditos nativos y extranjeros?

La consagración del modelo nagô de Salvador por estudiosos como Bastide se ve correspondida, en la actualidad, por una tendencia inversa: la que acompaña el desarrollo de las formaciones religiosas periféricas 
que no se codificaron ni en el candomblé ni en la umbanda. Ejemplo de este interés es el libro colectivo dirigido por Prandi (2001) e integrado por estudios sobre cultos otros. ¿Hasta dónde estas investigaciones no tienen como efecto frenar el proceso de homogeneización que ellas mismas revelan? El hincapié hecho en la especificidad del terecô, del tambor de mina o de la jurema por parte de los investigadores, ¿no logrará que los agentes refuercen los elementos diferenciales de su oferta a fin de responder a tal interés? Como pronto veremos, sin embargo, esta tendencia navega en dirección contraria al proceso de uniformización del campo.

Sea como sea, no podemos controlar el efecto de nuestra intervención en campo; desde bien temprano las agencias subalternas - en mayor o menor grado según la región y la religión - y los centros eruditos mantuvieron una relación en la que, de alguna manera, cada polo salió legitimado por el otro. Campo, los agentes concretos con los que trabaja en campo, legitima al investigador tanto cuanto el investigador lo hace con las agencias, los agentes concretos y, más allá, el universo global de la religiosidad subalterna. Esta relación se volverá más compleja dentro de poco; estos últimos tiempos están entrando en algunas maestrías alumnos que son "de santo", ¿cómo será su producción como investigadores de su propio mundo ${ }^{6}$ ?

\subsection{Las lógicas del campo}

Otra de las líneas parte de la evidente umbandización de las ceremonias descritas, cuestión sobre la que ya otros investigadores han trabajado en relación, no sólo a la jurema, sino a diversos fenómenos religiosos (lo que Assunção llama la "umbandización de los cultos populares", cf. 2001, p. 183). Esta umbandización tiene como correlato "simétrico e inverso" lo que en otra casa de jurema había yo presenciado en una visi- 
ta circunstancial en la que asistí a una roda que recordaba a las del candomblé, aunque no era de los orixás de éste de lo que se trataba, sino de Exus y Pombas Gira, espíritus de muertos ${ }^{7}$. Una canibalización tal no se limita al campo religioso, es toda la cultura popular la que está en juego; Maués y Villacorta (2001, p. 39) señalan que la Escola de Samba BeijaFlor triunfó en el carnaval carioca de 1998 con un samba enredo basado en la pajelança amazónica. En otra edición de este carnaval, una de las Escolas hizo girar su presentación sobre la gallina de angola, ave con un papel central en el candomblé. La cantidad de ejemplos similares que se pueden exponer sobre esta transversalidad son muchos. Son múltiples las circunstancias concretas que han posibilitado y fomentado estos intercambios, pero supongo que los flujos migratorios, las idas y vueltas, son un factor clave. Caroso y Rodrigues en el análisis de la dinámica de un terreiro del litoral norte bahiano afirman:

\begin{abstract}
[...] o processo de crescente umbandização dos candomblés de caboclo deve ser entendido no contexto do intenso fluxo migratório entre São Paulo e diferentes áreas da região Nordeste. Os migrantes que retornam à terra natal trazem na bagagem cultural modelos de culto urbanos que são reinterpretados ${ }^{8}$. (2001, p. 360)
\end{abstract}

Por cierto, esta influencia de la religiosidad de las grandes ciudades del centro-sur sobre las agencias nordestinas no es más que el pago diferido de los aportes religiosos que lo migrantes llevaron consigo décadas antes; por otro lado, ni las migraciones ni los intercambios religiosos se han producido sólo entre centros industriales-periferias, sino también entre diversas periferias entre sí y diversos centros industriales entre sí. Como hubiera dicho algún modernista, Brasil es un país de canibalismo generalizado. 
Ahora bien, estos procesos empíricos no ocurren al azar; una vez más, la estructura predomina sobre el acontecimiento. La idea que tengo es que hay lógicas estructurales potentes que actúan como fuerzas centrípetas en el campo religioso y que terminan por absorber a los cultos con lógicas más débiles. La umbanda y el candomblé, en su manera específica de organizarse como agencias, en su estilo de realizar rituales, en las topologías de sus centros de culto y del mundo que los rodea, en el propio universo de entidades con que una y otro operan, en lo que expresan sobre la sociedad brasileña como las "sociologías subalternas" que son (Giobellina Brumana y González Martínez, 1991 [1989], introdução), han llegado a la saturación combinatoria de los elementos con que opera, lo que les otorga una suerte de equilibrio, fuente de estabilidad y entidad.

En el caso de la umbanda, la lógica del sistema se expresa en su panteón, o, mejor en la interacción ritual de los miembros del panteón incorporados y los adeptos. Como he sostenido en otro sitio (Giobellina Brumana y González Martínez, 1991 [1989], cap. III), se esboza así un triángulo que opone la seriedad de caboclos y oguns, a la jocosidad de baianos, erês y marujos, y a lo sardónico de exu y pomba gira: espíritus que en tierra no ríen ni ante los cuales los adeptos ríen, espíritus que ríen con los humanos, espíritus cuya amenazadora risa hace que los presentes queden muy serios. Estas oposiciones en el teatro vivido ceremonial elaboran lo que podría verse como el mensaje central del culto: la oposición entre un ámbito doméstico, una casa donde se está en un dominio propio - donde ser ríe entre iguales - y un ámbito extraño, inquietante, peligroso, la calle, con sus dos polos, el de orden, la ley - la ley ajena -, y el desorden, la marginalidad. 


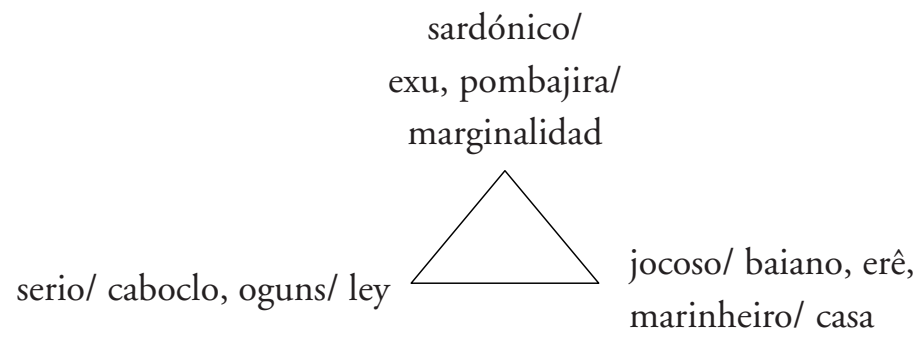

De esta manera, tanto bajo el esquema binario "derechas/ izquierda" ("bien/ mal", subrayando el entrecomillado) con que los umbandistas aluden a sus prácticas posibles y a las entidades místicas con las que operan en cada caso, cuanto bajo el polinómico por el que clasifican las diferentes "líneas" de espíritus, que conforman la fachada manifiesta de la "verdad" del culto, yace un sistema ternario en el que desde un ámbito propio se juega a dos bandas con lo que el sistema vigente categoriza como orden y desorden, bien y mal. Estamos en un punto cercano al que Jacobson-Widding (1979, p. 359) veía entre grupos de habla kikongo del bajo Congo en su empleo ritual de tres colores, el blanco representante del orden -, el negro - representante del desorden - y el rojo - representante de la neutralidad moral. El rojo - el vértice en el que se coloca el agente -, se opone a "blanco" y a "negro", en cuanto no se siente comprometido por los criterios de "correcto" e "incorrecto" con los que el sistema los define. Para el vértice oficial, continua la autora, para "el blanco, [...] hay dos clases de 'enemigos' del orden social. Uno de ellos es el desorden en términos de correcto e incorrecto y otro en términos de desorden". Este último punto, al menos pensado desde mi objeto, me provoca grandes dudas.

El polo vértice oficial, en lo que respecta a la religiosidad popular brasileña, es un producto de la construcción subalterna, un imaginario tejido con briznas de la impresión que el ubicuo "centro" tiene en las 
miradas del margen: el bricolaje, una vez más. No es un sujeto real que pueda agenciarse amigos o enemigos; es un construido en la disciplina de almas y cuerpos. Y el vértice "nuestro", el vértice doméstico, el "rojo" del ejemplo congoleño o del bahiano umbandista, no se mueve con indiferencia moral, sino más bien con una moral de la indiferencia: toda ética exterior, el "bien" y el "mal”, es una imposición, un sojuzgamiento que no cabe combatir. Aprovechar lo aprovechable y eludir lo que se aprovecha de uno, ése constituye el centro de la negociación perpetua a la que el margen está obligado.

En el caso del candomblé (Giobellina Brumana, 1994, cap. 3) nos encontramos ante dos triángulos, uno encajado en el otro. Por un lado, uno - presente en los meticulosos cuidados de los límites del ámbito sagrado, en tabúes, interdicciones, etc. - que opone la casa de santo a la casa doméstica y a la ciudad; es decir, el espacio sagrado en el que rige la ley de los orixás y dos espacios en los que rigen las leyes de este mundo, la familia y la sociedad global. El candomblé se propone así como una instancia alternativa al mundo circundante, pero no aspira a imponerse a él, sino tan sólo obtener un resquicio en el que poder existir.

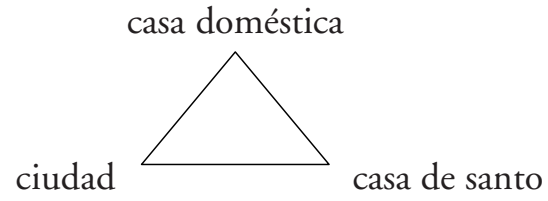

La casa de santo, por su parte, es una unidad indisoluble pero articulada en tres espacios rituales claramente diferenciados: la casa de Exu, el barracão con su cumieira y el roncô o peji. El primer ámbito es el de la separación con el mundo exterior, el de la protección contra todo lo negativo que de él provenga, el de la purificación de quienes 
vayan a ser objeto de cualquier ritual; al mismo tiempo es signo tanto de la unidad de la casa - ya que hay un Exu principal "dueño" de ese territorio -, cuanto de su pluralidad - ya que hay Exus de diversos orixás, asentados para diferentes adeptos. El barracón es el lugar de la unidad de la casa, donde se realizan todos los ceremoniales colectivos, donde la unidad y especificidad grupal están representadas por un recipiente de contenido secreto y de máxima sacralidad, la cumieira, fuente de la fuerza mística de la casa. Por último, el espacio de la pluralidad de la casa es el roncô, el recinto sagrado donde se guardan las vasijas en las que se asientan los dioses de cada adepto, donde se recogen los iniciantes, donde éstos se contaminan de aquellos, por la mano del pai-de-santo que derrama sobre sus cabezas y sobre las piedras en la que habitarán sus divinidades el axé de la sangre de los animales sacrificados y de las hierbas sagradas.

\section{roncô}

(multiplicidad de dioses y adeptos, identidad individual contaminación)

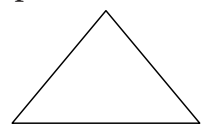

casa de exu barracão (unidad de la casa,

(unidad y multiplicidad de la casa, identidad grupal, fuerza mística) frontera, purificación)

En resumen, la umbanda y el candomblé, cada uno a su manera, se han construido como sistemas completos y consistentes, mientras que otros cultos subalternos, la jurema para no ir más lejos, se han quedado a medio camino de consolidarse como tales. En lo esencial, se trata de 
Revista de Antropologia, São Paulo, USP, 2005, v. 48 No 2.

agencias sin principios claros de organización, con funciones poco o mal jerarquizadas, panteones lábiles de personajes no estructurados.

El hecho de que la ceremonia en casa de D. Maria fuese prácticamente igual que la de un terreiro umbandista y que hasta se cantase el himno de la umbanda es correlativo a que el culto de jurema haya absorbido la figura de Exu, desplazando del centro de atención ceremonial a figuras originarias "malignas" (hay que subrayar mucho estas comillas) como la de Malunginho, al que ahora se identifica con un Exu más. Pero este pasaje de espíritus de un culto a otro no ha sido unívoco; se ha dado también el inverso de los baianos. Entre la umbanda y la jurema se ha producido un intercambio de entidades místicas que, en el caso de la primera, ha permitido su consolidación como sistema y que en el caso de la segunda ha significado la disolución de su especificidad.

Exu, a quien en el trabajo de João do Rio veíamos recluido de manera exclusiva en las casas de candomblé de fines del siglo XIX ha traspasado toda frontera. ¿Qué ha dado a Exu esa primacía que lo ha convertido en una figura transversal en toda la religiosidad subalterna, pasando del roncô del candomblé al terreiro umbandista, al centro de jurema y, como enemigo a combatir, al templo pentecostal? Una polisemia tal, es una especulación mía, debe provenir de una equivocidad primera, la que conjugó a Exu9 con el Diablo cristiano, llegándole a darle, en su representación iconográfica umbandista la forma que la vieja imaginería católica le había acordado: capa roja, tridente, rabo, etc. Este mecanismo permite operar con un elemento proveniente de un sistema dualista - Dios/Diablo, Bien/Mal - absorbiéndolo desde otro - ternario, polinómico - en el que las oposiciones nunca son antagónicas, en el que todos los elementos deben obligatoriamente entrar y permanecer en juego. Supongo que la distancia otorgada por el exotismo africano facilita el comercio con la figura demoníaca, pero no quiere en modo alguno esto decir que cuanto más referencias a los orígenes africanos de las prácticas místicas, 
más próximas están éstas a la hechicería. El catimbó clásico, tan poco afro, serviría para dar un mentís a esta hipótesis, también rebatida por el hecho de que la Pombajira, el Exu femenino, más emblemático, sea Maria Padilha, cuya proveniencia ibérica es notoria (Meyer, 1993).

El bahiano, en su reinvención umbandista del mestre catimbozeiro, debe haber ejercido como una suerte de imán que reunió figuras con cierto tono carnavalizante, como los espíritus de marineros, de gitanos de ambos sexos - versión light de exus y pombas giras -, el boiadero metáfora cómica del caboclo -, y buena parte de las crianças (aquellas que no son espíritus infantiles de alguna otra línea, como el exu mirim o el caboclo mirim). Esta agregación ha convertido a la umbanda en lo que es.

Ahora bien, este proceso de intercambio entre padrones religiosos se produjo dejando de lado una cantidad de entidades místicas presentes en cultos populares regionales, fruto muchas veces de la apropiación de material narrativo de origen europeo, como algún rey francés o el Sebastião portugués - sintetizado, como era imposible que no lo fuera, con el santo (y por esa vía con Oxosse), nobles portugueses o de procedencia indeterminada, espíritus turcos o egipcios, el propio Júpiter, etc. No creo posible dar una explicación al hecho de que la umbanda se haya apropiado de unos espíritus y no de otros; lo que sí sabemos es que lo que hoy conocemos como el repertorio del culto no permite la presencia de entidades singulares. El panteón umbandista es un panteón de "líneas", es decir, de estereotipos en los que se subsumen una cantidad indeterminada de miembros equivalentes; ésta es la característica que le otorga su apariencia clasificatoria. El candomblé, a su vez, es efectivamente clasificatorio porque consigue articular entidades individuales, los orixás, a una multitud de miembros de estas clases a su vez particularizadas por la relación con las cabezas de los "hijos de santo" correspondientes. 
Los espíritus del catimbó clásico son un conglomerado heterogéneo de entidades en el cual se pueden distinguir diversos tipos, pero que no constituyen un orden clasificatorio sistemático. Esta es una situación pareja a la del culto de los zar de Etiopía con los que Leiris trabajó en $1932^{10}$, con un panteón poco definido, en permanente crecimiento. Es similar también al culto venezolano de Maria Lionza, cuyo sistema de "cortes" (camareros, indios, africanos, vikingos, médicos, libertadores, malandros...) no es fijo, sino en evolución continua, añadiendo nuevas figuras, desplazando su significado, atribuyéndoles nuevos desempeños corporales durante la posesión. Así, como contrapunto al aumento de la violencia, en los últimos años diversos espíritus incorporados realizan prácticas de autoflagelación que llenan de sangre los centros, como de sangre están llenas las calles de las barriadas populares (Ferrándiz, 2005).

Se abre así un panorama cuyo solo atisbo produce vértigo, el sistema de los sistemas de posesión, la trama a la que de manera empírica refiere di Martino, para contextualizar el tarantismo de Lucania o a la que Leiris remite en el comienzo de su trabajo sobre Gondar: una topología espiritual que daría la vuelta al planeta, de la misma manera que los mitos que sueñan mitos de la gesta levi-straussiana.

\section{Notas}

1 Este texto forma de un trabajo mucho mayor, producto de una investigación realizada entre 2001 y 2004 financiado por el Plan Nacional de Investigación y Desarrollo de España.

2 Siguiendo la terminología nativa, entiendo por "espiritualista" toda manifestación religiosa basada explícitamente en la posesión; el repertorio muda según la región. Dejo de lado las denominaciones pentecostales que aunque opere extáticamente como ya mostraba Rodrigues Brandão hace un cuarto de siglo, no lo es de manera explícita y se enfrenta ardientemente a toda práctica espiritista. No obstante, es 
indudable el parentesco entre ambos flancos de la religiosidad popular brasileña, tanto por el transvase continuo de agentes, fieles y clientes, cuanto por el hecho de que en los templos evangélicos buena parte de las prácticas tienen como objeto a entidades de los otros cultos. Este parentesco no sólo es del orden del acontecimiento, sino de la estructura; en Umbanda. El poder del margen he mostrado como los cuatro principales cultos del campo religioso del centro sur de Brasil forman un sistema transformacional, en el lévi-straussianismo más riguroso.

3 Instituto Nacional da Tradição e Cultura Afro-Brasileiras, con sede en Salvador, cuyas autoridades máximas son Deoscoredes dos Santos y su esposa Joana Elbein.

4 El término "pedaço", según Magnani: "[...] designa aquel espacio intermediario entre lo privado (la casa) y lo público, donde se desarrolla una sociabilidad básica, más amplia que la fundada en los lazos familiares, sin embargo más densa, significativa y estable que las relaciones formales e individualizadas impuestas por la sociedad" (1984, p. 138). He tratado en mi libro sobre umbanda (Giobellina Brumana y González Martínez, 2000 [1989], p. 83-9) la relación “pedaço”-religiones subalternas.

5 He tratado la cuestión de la visita en Margen y poder (425ss). La visita del agente menor a un terreiro mayor y más estable tiene con frecuencia el objetivo de robarle clientes; esa era el caso del que fui testigo en mi trabajo sobre la umbanda de las incursiones del cearense en el terreiro de Roque o de la India en el de Cachachi.

6 Vagner Silva (1995 y 2000) nos presenta una descripción muy vívida de las relaciones academia-agencias religiosas a la que he accedido después de redactar estos párrafos. Sobre la obra de este investigador - y su relación "inversa y simétrica" con Cossard-Bignon - hablaré en otro texto en preparación; de todas maneras, quiero por de pronto destacar la sintonía que siento con sus desarrollos.

7 Mi cicerone en esa ocasión, Filipe Rios, muestra otro rasgo que esta casa de jurema había tomado del candomblé, una iniciación en la que el caboclo del iniciado grita su nombre, en el estilo del moruncô de las saídas de santo (Rios, 2001, p. 174). Sobre las voces del santo en el candomblé, cf. Giobellina Brumana (1994, cap. VIII).

8 Continúan diciendo algo que pronto nos será de provecho: "É neste processo de reinvenção religiosa que os exus ganham força, poder e prestígio".

9 Este personaje, Exu, es quizás sobre quien más curiosidad espontánea surge entre los fieles y agentes de los cultos en los que opera. Curiosidad que supera la simple 
manipulación mística, las formas de "trabajar" con él, y apunta a sus características teológicas: ¿cómo diferenciar el Exu de la umbanda - un espíritu de muerto - del del candomblé - una divinidad?, ¿̇se puede "hacer" Exu en la cabeza de un novicio?, ¿por qué generalmente no aparece en la roda de santo? etc.

10 La comparación es de Bastide, en carta a Leiris (1996, p. 909, n. 51). Cf. Giobellina Brumana (2005, cap. 6).

\section{Bibliografia}

ASSUNÇÃO, L.

2001

"Os mestres da jurema", in PRANDI, R. (org.). Encantaria brasileira. O livro dos mestres, caboclos e encantados, Rio de Janeiro, Pallas.

CALAVIA, O.

Fantasmas falados. São Paulo, Edusp.

CÂMARA CASCUDO, L.

1988 [1934] "Notas sobre o catimbó”, Novos Estudos Afro-Brasileiros, Recife. Massangana.

CAROSO, C. \& RODRIGUES, N.

2001 "Exus no candomblé de caboclo", in PRANDI, R. (org.). Encantaria brasileira.

O Livro dos mestres, caboclos e encantados, Rio de Janeiro, Pallas.

FERRÁNDIZ, F.

$1994 \quad$ Escenarios del cuerpo, Bilbao, Deusto.

GIOBELLINA BRUMANA, F.

1994 Las formas de los dioses. Sistema de clasificaciones y categorias en el Candomblé, Cádiz, Universidad de Cádiz.

2005 Soñando con los dogon. En los origenes de la etnografia francesa, Madrid, Consejo Superior de Investigaciones Científicas.

GIOBELLINA BRUMANA, F. \& GONZÁLEZ MARTÍNEZ, E. E. 1991 [1989] Marginália sagrada, Campinas, Ed. da Unicamp. 


\section{JACOBSON-WIDDING, A.}

Red-White-Black as a mode of thought. A study of triadic classifiction by colours in the ritual symbolism and cognitive thought of the peoples of the Lower Congo, Uppsala, Uppsala Studies in Cultural Anthropology.

LEIRIS, M.

1996

Miroir d'Afrique, Paris, Gallimard.

MAGNANI, J.

1984

Festa no pedaço, São Paulo, Brasiliense.

MARTINO, E. di.

1999 [1962] La tierra del remordimiento, Barcelona. Bellaterra

MAUÉS, R. H. \& VILLACORTA, G. M.

2001

"Pajelança e encantaria amazônica", in PRANDI, R. (org.). Encantaria brasileira. O Livro dos mestres, caboclos e encantados, Rio de Janeiro, Pallas.

MEYER, M.

1993

Maria Padilha e toda a sua quadrilha, São Paulo, Duas Cidades.

NAPAELS, M.

1998

"Une etrange etrangeté. Remarques sur la situation ethnographique", L'Homme, 148.

PRANDI, R. (org.).

2001 Encantaria brasileira. O Livro dos mestres, caboclos e encantados, Rio de Janeiro. Pallas.

RIO, J. do

1906 As religiōes no Rio, Rio de Janeiro, Garnier.

RIOS, L. F.

2001 "O catimbó-jurema do Recife", in PRANDI, R. (org.). Encantaria brasileira. O Livro dos mestres, caboclos e encantados, Rio de Janeiro, Pallas. 
Revista de Antropologia, São Paulo, USP, 2005, v. 48 № 2.

SILVA, V.

\begin{abstract}
Taking two Jurema ritual ceremonies as the starting point, this study concentrates on the analysis of some issues regarding the Brazilian religious universe. The main aspects brought into focus are, basically, the interactions between religious agencies and scholarly sectors interested in the study of marginal, secondary religions; the agencies networks - their cohesiveness, the various crossing paths they allow, the bonds between agents of different legitimacy etc.; the search for an operational value for syncretism; the homogenization of the universe, namely, the assimilation of rituals based on weak logical systems by rituals based on strong logical systems.
\end{abstract}

KEY-WORDS: popular religiosity, catimbó, jurema, umbanda, religious studies 